\title{
Nitrate respiration in chemoautotrophic symbionts of the bivalve Lucinoma aequizonata
}

\author{
Ute Hentschel, S. Craig Cary*, Horst Felbeck
}

University of California, San Diego, Scripps Institution of Oceanography, La Jolla, California 92093-0202, USA

\begin{abstract}
Chemoautotrophic bacteria live symbiotically in gills of Lucinoma aequizonata, an infaunal clam inhabiting an oxygen-poor environment. These intracellular symbionts respire nitrate, i.e. they use nitrate instead of oxygen as a terminal electron acceptor in the respiratory chain. Nitrate is only reduced to nitrite and not further to nitrogen gas. Nitrate is respired by the symbionts under fully aerobic conditions at the same rate as under anaerobic conditions. The bacterial symbionts contain a nitrate reductase that is associated with the membrane-containing fraction of the symbiont cell and that is sensitive to respiratory inhibitors; both features are consistent with the respiratory role of this enzyme. A review of nitrate reductase in chemoautotrophic symbionts suggests that nitrate respiration may be common among these symbioses. Symbiont nitrate reductase may be an ecologically important factor permitting the survival of animal hosts in oxygen-poor environments
\end{abstract}

\section{INTRODUCTION}

Many species of marine invertebrates harbor chemoautotrophic bacteria as symbionts (Southward 1983, Fisher 1990). These types of symbioses are generally established in environments characterized by a low species diversity. Since the discovery of the hydrothermal vents, symbioses of this kind have been found in reducing sediments (Cavanaugh 1983), seagrass beds (Fisher \& Hand 1984), pulpmill effluent sites (Reid 1980), brine and hydrocarbon seeps (Paull et al. 1984, Brooks et al. 1987), sewage outfalls (Felbeck et al. 1981) and anoxic basins (Felbeck et al. 1981). A common feature of these habitats is a disequilibrium mixture of reduced substrate (e.g. sulfide) and oxygen. Oxygen is required by the host for respiration, while the reduced substrate provides the energy for the chemoautotrophic metabolism of the symbionts.

All clams of the family Lucinidae so far examined harbor chemoautotrophic, sulfur-oxidizing bacteria as symbionts in specialized gill cells, the bacteriocytes (Allen 1958, Reid \& Brand 1986, Schweimanns \& Felbeck 1985, Distel \& Felbeck 1987). The symbiosis

\footnotetext{
- Present address: Department of Microbiology, Oregon State
} University, Corvallis, Oregon 97331-3804, USA with bacteria is correlated with physiological modifications in the functional morphology of the clam (e.g. enlargement of the gills and reduction of the feeding apparatus and the digestive system). Though it is now established that the symbionts provide a major part of the nutrition to the host, the exact mode of nutrient transfer is not understood (Fisher \& Childress 1986, Distel \& Felbeck 1988b).

A population of Lucinoma aequizonata lives in the Santa Barbara Basin, California, USA, at a narrow depth range of $500 \pm 10 \mathrm{~m}$ depth. Individuals live in 3 to $5 \mathrm{~cm}$ shallow burrows in the mud, which becomes anaerobic below the first few $\mathrm{mm}$ and contains sulfide only in randomly dispersed patches. L. aequizonata is adapted to the low oxygen, low sulfide environment in many ways, most evident by its slow metabolism and growth rates (Cary et al. 1989). Because the oxygen concentration of the overlying seawater is extremely depleted ( 5 to $7 \mu \mathrm{M}$ ) and the concentration of nitrate is ca $30 \mu \mathrm{M}$, we investigated whether the symbionts are capable of using nitrate instead of oxygen for the oxidation of sulfur compounds. The utilization of nitrate as a terminal electron acceptor for respiration is a metabolic trait of many free-living, facultatively anaerobic bacteria such as Thiobacillus denitrificans (Adams et al. 1971, Knowles 1982). Several lines of evidence have guided our research. Firstly, oxygen consumption 
could not be demonstrated in the L. aequizonata symbionts (Cary \& O'Brien unpubl.), which is indirect evidence for the presence of an alternative electron acceptor. Secondly, the symbionts have nitrate reductase activity, although it was previously assumed to be assimilatory (Felbeck et al. 1981). Thirdly, L. aequizonata lives in reducing sediments, which provide the necessary conditions for denitrification.

\section{MATERIALS AND METHODS}

Animal collection. Lucinoma aequizonata were collected at $500 \pm 10 \mathrm{~m}$ depth by otter trawl from the Santa Barbara Basin, California, USA, during 3 cruises in November 1989, July 1991 and November 1991 respectively. Immediately after recovery the clams were put in chilled seawater $\left(8^{\circ} \mathrm{C}\right)$ where they remained during transport to the laboratory. Clams were maintained in sediments from their natural habitat in flow-through aquaria at $8^{\circ} \mathrm{C}$. Clams used for the experiments were held in captivity not longer than $5 \mathrm{wk}$.

Isolation of bacteria. Symbiotic bacteria were isolated by Percoll density gradient centrifugation by the method of Distel \& Felbeck (1988a). All oxygen was removed from the buffers and reagents by bubbling with nitrogen gas for 15 min prior to use. Symbionts were extracted only from clams with yellow gills. The yellow color of the gills is due to energy reserves of the symbionts in the form of elemental sulfur, and it is inferred that symbionts with yellow gills are in good physiological condition (Vetter 1985). The gill tissue was removed and homogenized in a hand-held Dounce homogenizer with a loose-fitting pestle. The extract was layered on a cushion of $60 \%$ Percoll in imidazolebuffered saline ( $\mathrm{pH} 7.1$ ) and centrifuged to pellet the bacteria. Protein concentration was determined with the BCA protein assay (Pierce, Rockford, IL 61105, USA).

Determination of nitrite, nitrate and ammonium. The concentrations of nitrate, nitrite and ammonium in the seawater were determined as described in Gieskes \& Peretsman (1986). Nitrite was measured spectrophotometrically at $543 \mathrm{~nm}$ after reaction with sulfanilamide $(1 \%$ in $1 \mathrm{~N} \mathrm{HCl})$ and NED [N-(1-napthyl)-ethylene-diamine dihydrochloridel, $0.01 \%$ (w:v) Nitrate concentrations were determined after reduction to nitrite with a flow-through column containing coppercoated cadmium chips. Ammonium concentrations in the sample were measured photometrically at $640 \mathrm{~nm}$ after reaction with sodium hypochlorite and phenol.

Symbiont nitrate respiration. Anaerobic dissections were performed in a glove bag (Sigma, USA), all buffers and media were purged with nitrogen gas and the centrifugation was performed in capped centrifugation tubes. Symbiont nitrate respiration rates were measured at $8^{\circ} \mathrm{C}$ in $12 \mathrm{ml}$ of continuously stirred artifical seawater ( $\mathrm{pH}$ 7.5) containing $50 \mu \mathrm{M}$ nitrate and $100 \mu \mathrm{M}$ thiosulfate. Incubations were kept anaerobic by bubbling a continuous nitrogen stream with an injection needle through a rubber septum. Seawater samples were drawn with a syringe in $15 \mathrm{~min}$ intervals and centrifuged at $14000 \times g$ for $1 \mathrm{~min}$. For each of these samples, the concentrations of nitrate, nitrite and ammonium were determined in the supernatant. Symbiont oxygen respiration was measured in a respiration chamber (Strathkelvin Instruments, Glasgow, Scotlandj at $8^{\circ} \mathrm{C}$ while continuously stirred in $1.5 \mathrm{ml}$ of $0.2 \mu \mathrm{m}$ filtered seawater buffered to $\mathrm{pH} 7.5$ with $10 \mathrm{mM}$ MOPS [3-(N-morpholino) propanesulfonic acid]. Oxygen consumption was measured with a sulfide insensitive Clark-type oxygen electrode (Strathkelvin).

Aerobic nitrate respiration. Symbiont preparations were divided into 4 parts and incubated as described above at a protein concentration of ca $1 \mathrm{mg} \mathrm{ml}^{-1}$ in $10 \mathrm{ml}$ artificial seawater containing $1 \mathrm{mM}$ nitrate. One incubation was maintained anaerobic by continuous bubbling with nitrogen gas and a second one was maintained aerobic by constant bubbling with air. The third incubation was started anaerobically and was changed to aerobic conditions after $55 \mathrm{~min}$, while the fourth incubation was started aerobically and was changed to anaerobic conditions after $55 \mathrm{~min}$. The first timepoint was taken after 20 min to allow the symbionts to equilibrate to the respective incubation conditions. Subsamples were drawn at 5 min intervals, centrifuged ( $1 \mathrm{~min}$ at $14000 \times \mathrm{g}$ ), and the concentration of nitrite was determined in the supernatant.

Characterization of nitrate reductase. Isolated symbiont preparations were sonicated on ice $(5 \times 15$ s) and centrifuged ( $1500 \times g$ for $15 \mathrm{~min})$ to remove unbroken cells. The nitrate reductase activity of this crude extract was measured and represents the total nitrate reductase activity which was set equal to $100 \%$ (Table 1). An aliquot was boiled (5 min) and represents the inactivated control. The remaining extract was centrifuged ( $1 \mathrm{~h}$ at $46000 \times \mathrm{g}$ in a Sorvall RC-5B centrifuge), and the pellet was resuspended in $100 \mathrm{mM}$ degassed sodium phosphate buffer, $\mathrm{pH}$ 7.4. Nitrate reductase activity of the supernatant and the resuspended pellet was assayed according to a modified version of the protocol by Nicholas et al. (1979). The enzyme activity was measured colorimetrically with the amount of nitrate reduced to nitrite in the presence of benzyl viologen as an intermediate electron donor The reaction mixture contained a final concentration of $100 \mathrm{mM}$ phosphate buffer ( $\mathrm{pH} 7.4$ ), $5 \mathrm{mM}$ nitrate and $190 \mu \mathrm{M}$ benzyl viologen. The reaction mixture was continuously stirred and Paraffin oil $(400 \mu \mathrm{l})$ was 
Table 1 Lucinoma aequizonata. Concentrations of oxygen ${ }^{\circledR}$ (\% saturation, $\mu M$ ), nitrate and nitrite in the clam habitat. Rates of symbiont nitrate respiration ( $\mathrm{nmol} \mathrm{mg}^{-1}$ symbiont protein min ${ }^{-1}$ and $\mu$ mol nitrite $\mathrm{g}^{-1}$ gill wet wt $\mathrm{h}^{-1}$ ) are shown as well as the concentration of nitrite in the mantle water determined immediately after recovery of clams. nd: not determined

\begin{tabular}{|c|c|c|c|c|c|c|c|}
\hline & \multicolumn{2}{|c|}{$\mathrm{O}_{2}$} & $\begin{array}{l}\mathrm{NO}_{3}^{-} \\
(\mu \mathrm{M})\end{array}$ & $\begin{array}{l}\mathrm{NO}_{2}^{-} \\
\left(\mu \mathrm{M}^{-}\right.\end{array}$ & \multicolumn{2}{|c|}{$\mathrm{NO}_{3}^{-}$respiration rates } & $\begin{array}{c}\mathrm{NO}_{2}^{-} \text {in mantle water } \\
(\mu \mathrm{M})\end{array}$ \\
\hline Nov 1989 & 1.3 & 4.0 & 29.1 & 0.01 & $1.2 \pm 0.14(n=4)$ & nd & nd \\
\hline July 1991 & 2.2 & 6.7 & 31.5 & 0.01 & $0.35 \pm 0.11(\mathrm{n}=7)$ & $1.6 \pm 0.78(n=7)$ & $14.8 \pm 6(n=14)$ \\
\hline Nov 1991 & 2.1 & 6.3 & 31.9 & 1.01 & $0.22 \pm 0.01(n=4)$ & $0.88 \pm 0.1(n=4)$ & $6.6 \pm 4.3(n=17)$ \\
\hline
\end{tabular}

layered on top of the reaction mixture to prevent contact with air. The reaction was started by injecting sodium dithionite $(0.75 \mathrm{mM}$ final concentration) through the oil layer. After $10 \mathrm{~min}, 300 \mu \mathrm{l}$ aliquots were taken and the concentration of nitrite was determined.

To test the action of inhibitors on nitrate reductase, extracts of isolated bacteria were preincubated (15 $\mathrm{min})$ in the presence of antimycin A $(2.5 \mu \mathrm{M})$ or HOQNO (2-heptyl-4-hydroxyquinoline-N-oxide, $10 \mu \mathrm{M})$, both inhibitors of the respiratory chain between cytochromes $b$ and $c_{1}$ (Slater 1967), or the terminal oxidase inhibitor cyanide $(5 \mathrm{mM})$, before the enzyme activity was determined.

Induction of nitrate respiration. Clams were maintained in vessels containing 3.5 l seawater, $10 \mu \mathrm{M}$ thiosulfate and $10 \mu \mathrm{M}$ sulfide under the following conditions: (1) aerobic in nitrate-free seawater; (2) aerobic with addition of $1 \mathrm{mM}$ nitrate; (3) anaerobic in nitratefree seawater; and (4) anaerobic with addition of $1 \mathrm{mM}$ nitrate. After $8 \mathrm{~d}$, clams were sacrificed and the mantle water was collected by prying the shells apart with a scalpel. The fluid, generally 200 to $600 \mu \mathrm{l}$, was collected and the concentration of nitrite was determined. One gill demibranch was used for oxygen respiration measurements, while simultaneously the second demibranch was used for nitrate respiration. Nitrate respiration rates were measured by incubating the gill demibranch anaerobically in $1 \mathrm{mM}$ nitrate for $30 \mathrm{~min}$.

\section{RESULTS}

\section{Nitrate respiration in isolated symbiotic bacteria}

Nitrate was reduced by purified symbionts at rates up to $1.2 \pm 0.14 \mathrm{nmol} \mathrm{mg}$ protein ${ }^{-1} \mathrm{~min}^{-1}$ (Fig. 1). Nitrite appeared at the same rate that nitrate disappeared. After $60 \mathrm{~min}$, more than $80 \%$ of the nitrate initially present was reduced to nitrite. Nitrate respiration rates were measured after each cruise and are relatively constant over the 2 yr of observation (Table 1). Under identical conditions, nitrite did not appear in

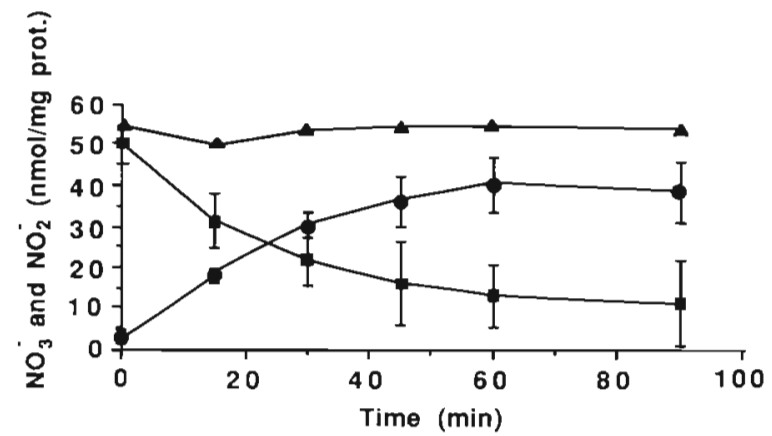

Fig 1 Lucinoma aequizonata. Anaerobic incubation, containing $50 \mu \mathrm{M}$ nitrate, of symbionts purified from clams. Symbols indicate the concentrations of nitrite (-), nitrate ( $\mathbf{m})$, and the sum of the 2 concentrations (4) in the seawater [nmol (mg symbiont protein $)^{-1}$, mean $\pm \mathrm{SD}, \mathrm{n}=3$ ]. Protein concentration was maintained at $1 \mathrm{mg} \mathrm{ml}^{-1}$

the absence of nitrate $(n=3)$ or symbiotic bacteria $(n=3)$. Moreover, no nitrite was produced when the bacteria were heat-killed ( $n=3$ ) or when preincubated in $5 \mathrm{mM}$ cyanide $(\mathrm{n}=3)$. Symbiont nitrate respiration could not be stimulated by 10 to $100 \mu \mathrm{M}$ thiosulfate $(\mathrm{n}=3)$ or by $50 \mu \mathrm{M}$ sulfide $(\mathrm{n}=3)$. Nitrate respiration did not persist below pH $7(n=12)$. The presence of nitrate under anaerobic conditions did not stimulate $\mathrm{CO}_{2}$ fixation. No use of nitrite could be detected when the bacteria were incubated in nitrite $(n=8)$. Nitrate was respired by the symbionts under fully aerobic conditions. Fig. 2 shows that the symbionts of these separate preparations respired nitrate at a relatively constant rate under all 4 incubation conditions.

\section{Characterization of nitrate reductase}

Much of the total activity $(81 \pm 5 \%)$ was localized in the membrane containing fraction $(\mathrm{n}=3)$, and $13 \pm 1 \%$ of the total enzyme activity was recovered in the supernatant $(n=3)$. No enzyme activity was measured in the non-symbiont-containing mantle tissue and the dead control (Table 2). 


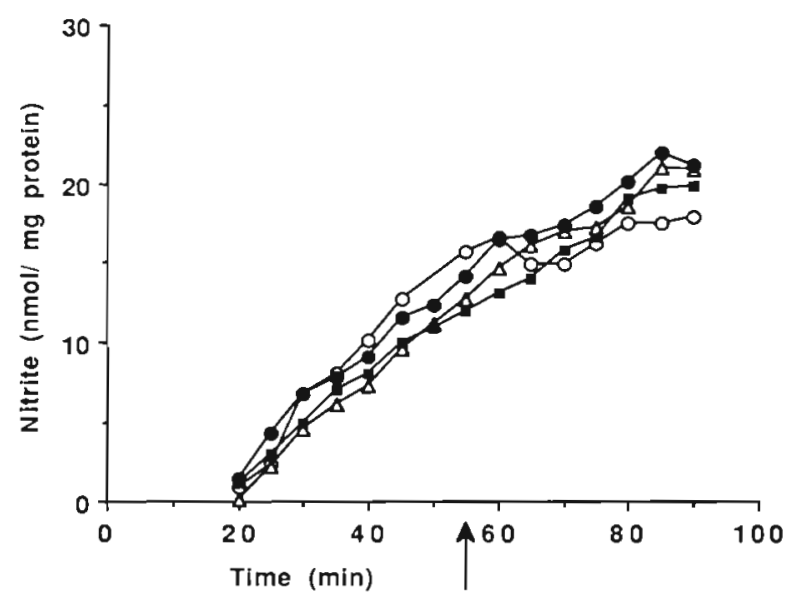

Fig. 2. Lucinoma aequizonata. Incubation of purified symbionts in seawater containing $1 \mathrm{mM}$ nitrate under 4 different conditions. The nitrite production under aerobic (•) and anaerobic $(0)$ conditions is shown as well as during a change from anaerobic to aerobic $(\Delta)$ and aerobic to anaerobic (-) conditions. The change is indicated by the arrow. Replicates $(n=3)$ showed similar results (data not shown)

Nitrate reductase enzyme activity was inhibited by antimycin A ( $62 \%$ inhibition), HOQNO $171 \%$ inhibition) and cyanide (100\% inhibition). Azide interferes with the test for nitrite and thus cannot be used as an inhibitor.

\section{Induction of nitrate respiration}

Highest nitrate respiration rates were measured in yellow gills of clams maintained anaerobically in the presence of nitrate $\left(23 \pm 4 \mathrm{mmol}\right.$ nitrite $\mathrm{g}^{-1}$ wet wt $\min ^{-1}, n=4$; Table 3 ). Four negative controls were conducted. Firstly, nitrite did not appear when the gill tissue was boiled $(n=6)$. Secondly, when non-symbiontcontaining tissue (gonad) was incubated, nitrite appeared at a rate of $1.2 \pm 1 \mathrm{nmol} \mathrm{g}^{-1}$ wet wt $\mathrm{min}^{-1}$ $(n=6)$. Thirdly, black gills were used as internal negative controls because the symbiont population is depleted (Cary et al. in press) although they should have the same number of free-living bacteria (Vetter 1985). The respiration rates of black gills were measured for each of the 4 maintenance conditions. The nitrate respiration rates were below the detection limits after aerobic maintenance ( $\mathrm{n}=5$ ), $9 \pm 3 \mathrm{nmol}$ nitrite $\mathrm{g}^{-1}$ wet wt min $^{-1}$ after aerobic + nitrate maintenance $(n=6), 4$ $\pm 6 \mathrm{nmol} \mathrm{g}{ }^{-1}$ wet wt $\mathrm{min}^{-1}$ after anaerobic maintenance $(n=4)$, and $8.4 \pm 3 \mathrm{nmol}$ nitrite $\mathrm{g}^{-1}$ wet wt $\mathrm{min}^{-1}$ after anaerobic + nitrate maintenance $(n=7)$. Fourthly, the appearance of nitrite in the seawater is an indicator for symbiont nitrate respiration in the intact symbiosis. When animals were maintained anaerobically in sea.
Table 2. Lucinoma aequizonata. Nitrate activity in different fractions of symbionts purified from clams. The total activity of the crude extract before centrifugation represents $100 \%$ $(n=3)$. Mantle tissue and boiled extract serve as controls

\begin{tabular}{lc|}
\hline Cell fraction & $\mathrm{NO}_{3}{ }^{-}$- reductase activity $(\%)$ \\
\hline Crude exract & 100 \\
Membrane & $81 \pm 5$ \\
Supernatant & $13 \pm 1$ \\
Mantle & 0 \\
Dead control & 0 \\
Total & $94 \pm 5$ \\
\hline
\end{tabular}

water containing $30 \mu \mathrm{M}$ nitrate, nitrite appeared at a linear rate until $10 \mu \mathrm{M}$ nitrite were present after $7 \mathrm{~d}$.

Oxygen respiration rates were always higher in yellow gills than in black gills and always higher in clams maintained anaerobically than aerobically. The oxygen respiration rates for black gills were $11.6 \pm 7 \mathrm{nmol}$ oxygen $\mathrm{g}^{-1}$ wet wt $\mathrm{min}^{-1}$ after aerobic maintenance (n $=5), 11.6 \pm 6 \mathrm{nmol} \mathrm{g}^{-1}$ wet $\mathrm{wt} \mathrm{min}{ }^{-1}$ after aerobic $+\mathrm{ni}-$ trate maintenance ( $n=4), 31 \pm 17$ nmol oxygen $\mathrm{g}^{-1}$ wet wt $\min ^{-1}$ after anaerobic maintenance $(n=4)$ and 25.9 $\pm 8 \mathrm{nmol}$ oxygen $\mathrm{g}^{-1}$ wet wt $\mathrm{min}^{-1}$ after anaerobic maintenance $(n=7)$.

\section{DISCUSSION}

The utilization of nitrate for respiration is well-documented in free-living bacteria from anaerobic environments and is also known in the Rhizobium-legume symbiosis (Zablotowicz et al. 1978, O'Hara et al. 1983). In nitrate respiration nitrate is used as a terminal electron acceptor of the respiratory chain. Nitrate can either be reduced to nitrite (nitrate respiration) (Stewart 1988) or further to nitrogen gas (denitrification) (Knowles 1982). Cary et al. (1989) suggested that the symbionts of Lucinoma aequizonata might resemble Thiobacillus denitrificans in using nitrate for respiration. The enzyme nitrate reductase had been reported in several chemoautotrophic symbioses including $L$. aequizonata, however, it has previously been considered assimilatory (Felbeck et al. 1981).

\section{Symbiont nitrate respiration}

In this study we demonstrate the presence of a respiratory nitrate reductase as well as nitrate respiration in purified symbiont preparations. Two different nitrate reductases are known in bacteria: type $B$ is assimilatory and restricted to the cytosol, while type $A$ is respiratory and bound to the membrane (Pichinoty et 
al. 1969, Hochstein 1988). The localization of most of the enzyme activity in the membrane containing fraction (Table 2) indicates its respiratory function. This role is also supported by the effects of respiratory inhibitors. The relatively small amount of enzyme activity remaining in the supernatant may be due to an assimilatory nitrate reductase or it may be the result of small membrane particles which were not pelleted during centrifugation.

The symbionts of Lucinoma aequizonata would be classified as nitrate respirers, because nitrate is quantitatively reduced to nitrite (Fig. 1). Nitrate is respired at a maximal rate in the first $15 \mathrm{~min}$ and the rates drop until they level off after $60 \mathrm{~min}$ at a nitrate concentration of $15 \mu \mathrm{M}$. The reason for this drop off is as yet unknown but is most likely dependent on the low concentration of nitrate in the medium. In the experiment shown in Fig. 2 the nitrate concentration was 20 times higher and nitrite accumulated linearly over the entire period.

The production of nitrite can also be observed in mantle water of freshly collected clams and clams maintained in the laboratory (Tables $1 \& 3$ ). Since the concentration of nitrite in seawater is typically lower than $10 \mathrm{nM}$ this nitrite can only come from bacteria inside of the clams. Several results proved that nitrite appearance was indeed due to the symbionts and not free-living contaminants in the gill area: (1) only minute quantities of nitrite appeared in incubations of gonadal tissue or in clams from which the gills had been removed and (2) black gills had much lower nitrate respiration rates. $L$. aequizonata with black gills are described as having a depleted or inactive symbiont population (Cary et al. in press). Assuming the external contamination of the gills was similar as in yellow gills, an incubation of black gills should, therefore, result in lower nitrate respiration rates, if the use of nitrate could be attributed to the symbionts. This was the case in all experiments.

\section{Induction of nitrate respiration}

Highest symbiont nitrate respiration rates were measured after the clams were maintained in the pres- ence of nitrate (Table 3). Such clams also had the highest concentration of nitrite in the mantle water. Nitrate respiration rates and the concentration of nitrite in the mantle water of these clams were not significantly different, whether the clams were maintained aerobically or anaerobically, On the other hand, much lower nitrate respiration rates were measured in symbionts of clams, which were maintained without nitrate. Again, the nitrate respiration rates were statistically not different whether the clams were maintained in the presence or absence of oxygen. We can, therefore, conclude that the induction of nitrate reductase synthesis in vivo is caused by the presence of nitrate and is unaffected by oxygen

\section{Quantitative significance of nitrate respiration}

The rates of symbiotic nitrate respiration were measured after each cruise and range from 0.22 to $1.2 \mathrm{nmol}$ $\mathrm{mg}^{-1} \mathrm{~min}^{-1}$ (Table 1 ). These rates are comparable to $\mathrm{CO}_{2}$ fixation rates $\left(1 \mathrm{nmol} \mathrm{mg}^{-1} \mathrm{~min}^{-1}\right.$ ) of the symbionts (Distel \& Felbeck 1988b). Nitrate respiration in whole gills is 20 to $50 \%$ of the oxygen respiration rates of the gills (Table 3 ). These numbers clearly indicate the quantitative importance for the overall metabolism of the symbiosis.

\section{Aerobic nitrate respiration}

Free-living bacteria usually respire nitrate under anoxic conditions (Payne 1973, Stouthamer 1980, 1988, Tiedje 1988), only a few free-living bacteria are known for aerobic denitrification (Krul \& Veeningen 1977 , Meiberg et al. 1980, Robertson \& Kuenen 1984a, b, Lloyd et al. 1987, Robertson et al. 1988) or co-respiration of oxygen and nitrate (Bonin \& Gilewicz 1991). These bacteria are denitrification specialists and do not shut down their denitrification enzymes in response to oxygen.

The results of our study suggest that symbiont nitrate respiration is specialized as well: nitrate reductase may be constitutive and a mechanism for oxygen as a termi-

Table 3. Lucinoma aequizonata. Rates of nitrate and oxygen respiration ( $\mathrm{nmol} \mathrm{g}^{-1}$ wet wt min ${ }^{-1}$ ) in yellow gills and the concentration $(\mu \mathrm{M})$ of nitrite in the mantle water of clams which were maintained under 4 different conditions for $8 \mathrm{~d}$ (aerobic, aerobic + $1 \mathrm{mM}$ nitrate, anaerobic, anaerobic + $1 \mathrm{mM}$ nitrate)

\begin{tabular}{lccc|}
\hline Condition $(8 \mathrm{~d})$ & $\mathrm{NO}_{3}{ }^{-}$respiration & & $\mathrm{NO}_{2}{ }^{-}$in mantle water \\
\hline Aerobic & $4.2 \pm 5(\mathrm{n}=5)$ & $20.8 \pm 10(\mathrm{n}=5)$ & $6.4 \pm 3(\mathrm{n}=11)$ \\
Anaerobic & $8.4 \pm 4(\mathrm{n}=4)$ & $35.2 \pm 10(\mathrm{n}=4)$ & $8.3 \pm 6(\mathrm{n}=10)$ \\
Aerobic + nitrate & $21.6 \pm 6(\mathrm{n}=5)$ & $34.4 \pm 9(\mathrm{n}=5)$ & $148 \pm 78(\mathrm{n}=10)$ \\
Anaerobic + nitrate & $23.0 \pm 4(\mathrm{n}=4)$ & $39.2 \pm 2(\mathrm{n}=4)$ & $157 \pm 50(\mathrm{n}=11)$ \\
\hline
\end{tabular}


nal acceptor may be absent. This hypothesis is based on the following observations. Firstly, oxygen consumption could not be demonstrated to date (S. C. Cary \& J. O'Brien unpubl data). This could result from damage during isolation or because the rates of oxygen consumption might be below detection limit. Since, however, nitrate respiration can be measured under the same conditions, it may be that the symbionts generally use nitrate and not oxygen for respiration. Secondly, the symbionts respire nitrate at the same rate under aerobic and anaerobic conditions (Fig. 2). It is apparent that symbiont nitrate respiration is not sensitive to oxygen. The usual mechanism of the inhibition of nitrate respiration by oxygen is the competition of the 2 terminal enzymes for electrons. The electrons are directed preferably to oxygen for energetic reasons. This choice may not be possible in the symbiont respiratory chain. Thirdly, even when the clams were maintained in aerobic seawater for several weeks, the symbionts continued to respire nitrate but not oxygen

In summary, the nitrate reductase of the symbionts may not be affected by the external concentration of oxygen but solely by the intracellular environment around the bacteria. In their natural environment, the bacteria are exposed to little, if any, oxygen because (1) the environmental levels of oxygen in the seawater around the clams are below $3 \%$ saturation and (2) an intracellular hemoglobin in the host tissue with a high affinity to oxygen (Kraus \& Wittenberg 1990) may protect the symbionts from oxygen.

Since the host requires oxygen for its metabolic needs, this avoidance of competition for scarce resources between the symbiotic partners may have been a major evolutionary advantage in allowing this organism to colonize a habitat where not many other species can be found.

Acknowledgements. We thank Becky Streib and Sandy Wiley for assistance and support during this research, the captain and crew of the RV 'Robert Gordon Sproul' for their patience during our collecting efforts, John O'Brien, Jeft Stein, Bill Cochlan and Andrew Woods for helpful discussions and Nick Holland for his careful review of the manuscript. Supported by NSF grants OCE-8610512 and OCE 90-11835 to H.F. and a UCSD Biomedical Research Grant to S.C.C.

\section{LITERATURE CITED}

Adams, C. A., Warnes, G. M., Nicholas, D. J. D. (1971). A sulphite-dependent nitrate reductase from Thiobacillus denitrificans. Biochim. Biophys. Acta 235: 398-406

Allen, J. A. (1958). On the basic form and adaptations to the habitat in the Lucinaceae (Eulamellibranchia). Phil. Trans. R. Soc. Lond. Ser. B. 241: 421-484

Bonin, P, Gilewicz, M. (1991). A direct demonstration of co-respiration of oxygen and nitrogen oxides by Pseudomonas nautica: some spectral and kinetic properties of the respiratory components. FEMS Microb. Letters 80: $183-188$

Brooks, J. M., Kennicutt, M. C., Fisher, C. R., Macko, S. A., Cole, K., Childress, J. C., Bidigare, R. R., Vetter, R. D. (1987). Deep-sea hydrocarbon seep communities: evidence for energy and nutritional carbon sources. Science 238: $1138-114$

CalCOFI data report. SIO physical, chemical and biological data report: CalCOFI cruises 8911. SIO reference 90-19. 1989. CalCOFI cruises 9007, 99011. SIO reference 91-18. 1991

Cary, S. C., Novitsky, T J., Hentschel, U., Felbeck, H. (in press). Biomass assessment of bacterial endosymbionts in specialized tissues of marine invertebrates using the Limulus lysate assay to monitor lipopolysaccharides. Mar. Biol.

Cary, S. C., Vetter, R. D., Felbeck, H. (1989). Habitat characterization and nutritional strategies of the endosymbiontbearing bivalve Lucinoma aequizonata. Mar. Ecol. Prog. Ser. 55: $31-45$

Cavanaugh, C. M. (1983). Symbiotic chemoautotrophic bacteria in marine invertebrates from sulfide-rich habitats. Nature 302: 58-61

Distel, D. L., Felbeck, H. (1987). Endosymbiosis in the lucinid clams Lucinoma aequizonata, Lucinoma annulata and Lucina floridana: a reexamination of the functional morphology of the gills as bacteria-bearing organs. Mar. Biol. 96: 79-86

Distel, D. L., Felbeck, H. (1988a). Pathways of inorganic carbon fixation in the endosymbiont-bearing lucinid clam Lucinoma aequizonata. Part 1. Purification and characterization of the endosymbiotic bacteria. J. exp. Zool. 247: $1-10$

Distel, D. L., Felbeck, H. (1988b). Pathways of inorganic carbon fixation in the endosymbiont-bearing lucinid clam Lucinoma aequizonata. Part 2. Analysis of the individual contributions of host and symbiont cells to inorganic carbon assimilation. J exp. Zool. 247: 11-22

Felbeck, H., Childress, J. J., Somero, G. N. (1981). CalvinBenson cycle and sulfide oxidation enzymes in animals from sulfide-rich habitats. Nature 293: 291-293

Fisher, C. (1990). Chemoautotrophic and methanotrophic symbiosis in marine invertebrates. Crit. Rev. Aquat. Sci. 2: $399-435$

Fisher, C., Childress, J. J. (1986). Translocation of fixed carbon from symbiotic bacteria to the host tissues in the gutless bivalve, Solemya reidi. Mar. Biol. 93: 59-68

Fisher, C., Hand, S. (1984). Chemoautotrophic symbionts in the bivalve Lucina floridana from seagrass beds. Biol. Bull. 167: $445-459$

Gieskes, J., Peretsman, G. (1986). Water-chemistry procedures aboard Joides Resolution-some comments. Ocean drilling program. Texas A\&M University, Technical Note No. 5: $1-46$

Hochstein, L. I. (1988). The enzymes associated with denitrification. A. Rev. Microbiol. 42: 231-261

Knowles, R. (1982). Denitrification. Microbiol. Rev, 46: 43-70

Kraus, D. W., Wittenberg, J. B. (1990). Hemoglobins of the Lucina pectinata / bacteria symbiosis. J. biol. Chem. 265: 16043-16053

Krul, J. M., Veeningen, R. (1977). The synthesis of the dissimilatory nitrate reductase under aerobic conditions in a number of denitrifying bacteria isolated from active sludge and drinking water. Water Res. 11: 39-43

Lloyd, D., Boddy, L., Davies, K. (1987). Persistence of bacterial 
denitrification capacity under aerobic conditions: the rule rather than the exception. FEMS Microbiol. Ecol. 45: $185-190$

Meiberg, J., Brunnenberg, P., Harder, W. (1980). Effect of dissolved oxygen tension on the metabolism of methylated amines in Hydromicrobium $X$ in the absence and presence of nitrate: evidence for 'aerobic' denitrification. J. gen. Microbiol. 120: 453-463

Nicholas, D. J. D., Ferrante, J. V., Clarke, G. R. (1979). Immunological studies with nitrogenase from Azotobacter and bacterial nitrate reductases. Anal. Biochem. 95: 24-31

O'Hara, G., H., Daniel, R. M., Steele, K. W. (1983). Effect of oxygen on the synthesis, activity and breakdown of the Rhizobium denitrification system. J. gen. Microbiol. 129: 2405-2412

Paull, C. K., Hecker, B., Commeau, R., Freeman-Lynde, R. P., Newman, C., Corso, W. P., Golubic, S., Hook, J. E., Sikes, E., Curray, J. (1984). Biological communities at the Florida escarpment resemble hydrothermal vent taxa. Science 226: $965-967$

Payne, W. J. (1973). Reduction of nitrogenous oxides by microorganisms. Bact. Rev. 37: 409-452

Pichinoty, F., Azoulay, P., Couchoud-Beaumont, L., LeMinor, R., Rigano, C., Bigliardi-Rouvier, J., Piechoud, M. (1969). Recherche de nitrate-reductases A et B: resultats. Annls Inst. Pasteur 116: 27-42

Reid, R. G. B. (1980). Aspects of the biology of a gutless species of Solemya (Bivalvia: Protobranchia). Can. J. Zool. 58: 386-393

Reid, R. G. B., Bernard, F. R. (1980). Gutless bivalves. Science 208: 609-610

Reid, R. G. B., Brand, R. G. B. (1986). Sulfide-oxidizing symbiosis in lucinaceans: implications for bivalve evolution Veliger 29: 3-24

Robertson, L. A., Kuenen, J. G. (1984a). Aerobic denitrification: a controversy revived. Arch. Microbiol. 139: 531-354

Robertson, L.A., Kuenen, J. G. (1984b). Aerobic denitrifica-

This article was presented by F. Azam, La Jolla,

California, USA tion: old wine in new bottles? Antonie van Leeuwenhoek 50: $525-544$

Robertson, L. A., Van Niel, E., Torremans, R., Kuenen, J. G., (1988). Simultaneous nitrification and denitrifıcation in aerobic chemostat cultures of Thiospaera pantotropha. Appl. environ. Microbiol. 54: 2812-2818

Schweimanns, M. Felbeck, H. (1985). Significance of the occurrence of chemoautotrophic bacterial endosymbionts in lucinid clams from Bermuda. Mar. Ecol. Prog. Ser. 24: $113-120$

Slater, E. C. (1967). Application of inhibitors and uncouplers for a study of oxidative phosphorylation. Meth. Enz. 10: $48-57$

Southward, E. C. (1983). Contribution of symbiotic chemoautotrophs to the nutrition of benthic invertebrates. In: Sleigh, M. A. (ed.) Microbes in the sea. Ellis Horwood Ltd, Chichester, p. 83-118

Stewart, V. (1988). Nitrate respiration in relation to facultative metabolism in enterobacteria. Microbiol. Rev. 52: 190-232

Stouthamer, A. H., Van't Riet, J., Oltmann, L. F. (1980). Respiration with nitrate as an acceptor. In: Knowles, C. J. (ed.) Diversity of bacterial respiratory systems. CRC Press, Boca Raton, p. 19-48

Stouthamer, A. (1988). Dissimilatory reduction of oxidized nitrogen compounds. In: Zehnder, A. J. B. (ed.) Biology of anaerobic microorganisms. Wiley, New York, p. 245-303

Tiedje, J. M., (1988). Ecology of dentrification and dissimilatory nitrate reduction to ammonium. In: Zehnder, A. J. B. (ed.) Biology of anaerobic microorganisms. Wiley, New York, p. 179-244

Vetter, R. (1985). Elemental sulfur in the gills of three species of clams containing chemoautotrophic symbionts: a possible energy storage compound. Mar. Biol. 88: 33-42

Zablotowicz, R. M., Eskew, D. L., Focht, D. D. (1978). Denitrification in Rhizobium. Can. J. Microbiol. 24: $757-760$

Manuscript first received: March 16, 1992

Revised version accepted: January 7, 1993 